\title{
EFFECT DIRECT AND INDIRECT (INQUIRY) INSTRUCTIONS MODEL IN TEACHING GYMNASTICS
}

\author{
Helmy Firmansyah \\ Faculty Of Sports And Health Edutation, Indonesia University Of Education \\ helmy.firmansyah@upi.edu
}

\begin{abstract}
To do the gymnastic floor movement needs a good skill, it is because gymnastic is a physical activity that helps to optimise the growth of children, and also gymnastic give a huge contribution in a basic fundamental moves development which is important to other sport activities, especially in terms of how we control the body efficiently and effectively. There are some problems in the implementation of gymnastics, like the students are afraid to do it, feel aching of their body after doing gymnastics, and they also have trauma for it, etc. Those things are caused of unsatisfied result of the lessons or they could not achieve minimum score in gymnastic subject. Therefor, the researchers used direct and indirect ( inquiry ) instruction lessons to comprehend the differences between them in gymnastic subject. The method which used is an experiment with Pre-test Post-test Control Group Design. The population of this research is 200 students of SMA N 1 Haurgeulis in 10 grade and using random technique simple which is 40 students as samples. The instrument used in this study was the measurement of psychomotor measurement. Based on calculations and data analysis can be concluded that for direct instruction obtained p-value $(0.000)<\alpha(0.05)$ then $\mathrm{H}_{0}$ is rejected. For indirect instruction (inquiry) obtained p-value $(0.000)<\alpha(0.05)$ then $\mathrm{H}_{0}$ is rejected. The conclusion of this study is that there is a direct influence learning direct and indirect (inquiry) instructions with the result of gymnastic subject in SMA N 1 Haurgeulis.
\end{abstract}

Keywords: direct, indirect instruction, gymnastics

\section{INTRODUCTION}

Gymnastics is a physical exercises designed to develop the strength and coordination of the body. It consist 3 kinds, such as : basic, artistic and rhythmic gymnastics. Artistic gymnastics can be done with or without tools. Gymnastics which can be done without tools named gymnastics floor, and the other one named gymnastics apparatus. There are so many moves in the gymnastics floor, neither springy, flips even the balance of the body. While, the easiness and the difficulty to do the moves is depending with the elements of the move, even it is good or bad. For example : flexibility, accuracy, balance, and agility of the person who does the gymnastics.

To do the moves in the gymnastics floors needs a good skills because gymnastics is a physical activity that helps to optimise the growth of children. Very appropriate gymnastic movements to get the emphasis in physical education programs, mainly because of the physical demands required, such as strength and durability of the muscles of the entire body. Besides, gymnastic give a huge contribution in a basic fundamental moves development which is important to other sport activities, especially in terms of how we control the body efficiently and effectively.

We often encounter various problems both experienced by teacher or student, some of the problems include a lack of implementation models and varied approaches in gymnastic activities. For example, There are some problems in the implementation of gymnastics, like the students are afraid to do it, feel aching of their body after doing gymnastics, and they also have trauma for it, etc. Those things are caused of unsatisfied result of the lessons or they could not make the move as its should be.

To knowing the result of the lessons process that has been done, we can see from the result that has been achieved from the students. Bloom (1956) in (Rudi Susilana 2006, p. 102) explained there are 3 results of the lesson, such as : cognitive, affective, and psychomotor. To cognitive aspect, Bloom said " 6 levels such as : knowledge, comprehension definition, application, analysis, evaluation". 
According to the description before we can conclude that basically the process of learning can be marked with all the progress of behaviour neither cognitively, affectively or psychomotor. The process of progress itself can happen with a simple thing until the complex one which is the solution, and the importance thing is the role of the personality in the process and the result. Generally, the result of the students could be influenced with the internal factor, that is the things in the students and the external factor which is the outside things of the students.

The problems that have been explained above can be solved with some of alternative solutions, like manipulated the result of the lessons. There are so many models of the lessons that can be done by teacher to deliver the material in order to make the students understand that has been given. But, along the health and sports education development, the models of the lesson are growing. Joyce and Weil (in a book titled Juliantine, 2013 p. 8) said "The lessons models are plans or patterns which can be used to make a curriculum (longterm lessons plan), designed the materials of the lessons and guide the students at class. According to Joyce and Weil also said that there are 4 models in the models of the lesson itself such as : Processing information model, Private model, Social interaction, and Behaviour models.

\section{RESEARCH METHODOLOGY}

In a research study design needed to be a reference to be used as a reference in research steps. Nasution (2004) says "The research design is a plan on how to collect and analyse the data in accordance with the purpose of research". The use of design in this study was pre-test post-test control group design with two groups of recipients treatments (p. 40). The shape of the research design is as follows

Research Design

Pretest post-test control group design

$$
\begin{array}{llll}
R & \mathrm{O}_{1} & \mathrm{X}_{1} & \mathrm{O}_{2} \\
\mathrm{R} & \mathrm{O}_{3} & \mathrm{X}_{2} & \mathrm{O}_{4}
\end{array}
$$

Information :

$\mathrm{R}$ : Sample the research group

$\mathrm{O}_{1}$ : Values group pretest direct learning model (direct instruction)

$\mathrm{O}_{2}$ : Value post-test group of direct learning model (direct instruction)

$\mathrm{O}$ 3: Value pretest group inquiry learning model (indirect instruction)

$\mathrm{O}$ 4: Value post-test group inquiry learning model (indirect instruction)

$\mathrm{X}{ }_{1}$ : Treatment (treatment) direct learning model (direct instruction)

$\mathrm{X}_{2}$ : Committing (treatment) inquiry learning model (indirect instruction)

\section{RESULT \& DISCUSSION}

After doing research on two experimental groups and the control group, in which the experimental group using direct learning model (direct instruction) and the control group using model indirectly (indirect instruction) towards learning gymnastics floor in SMA Negeri 1 Haurgeulis who have obtained the data. For more details can be seen in the following table:

Direct Learning Models

ANOVA

Test Scores Tiger Sprong

\begin{tabular}{lccccc}
\hline & Sum of Squares & df & mean Square & F & Sig. \\
\hline Between Groups & 297025 & 1 & 297025 & 262793 & .000 \\
Within Groups & 42950 & 38 & 1,130 & & \\
\hline Total & 339975 & 39 & & & \\
\hline
\end{tabular}


- hypothesis statistical

$\mathrm{H}$ o: No effect of pre-test and post test in tiger's jump.

$\mathrm{H}_{1}$ : There is the influence of pre-test and post-test in the tiger's jump.

- Signification standart

In this case used a significance level of $\alpha=$ $5 \%(0.05)$

- Rejection criteria

$\mathrm{H} 0$ is rejected if the $p$-value $<\alpha(0.05)$ or $\mathrm{F}$ hit> F table

- Decision
Based on the above output is known that $p$ value $(0.000)<\alpha(0.05)$ then $\mathrm{H}_{0}$ is rejected. So there is the influence of pre-test and post-test in the tiger's jump.

- Conclusion

It can be concluded no effect (improving student learning outcomes after given treatments using direct learning model on the pre-test and post-test on the test tiger's jump in SMA Negeri 1 Haurgeulis.

Test Carthweel

ANOVA

Test Scores Carthweel

\begin{tabular}{lccccc}
\hline & Sum of Squares & Df & mean Square & F & Sig. \\
\hline Between Groups & 422500 & 1 & 422500 & 321743 & .000 \\
Within Groups & 49,900 & 38 & 1,313 & & \\
\hline Total & 472400 & 39 & & & \\
\hline
\end{tabular}

- hypothesis statistical

$\mathrm{H}_{0}$ : No effect of pre-test and post-test in the test Carthweel.

$\mathrm{H}_{1:}$ There is the influence of pre-test and post-test in the test Carthweel.

- Signification standart

In this case used a significance level of $\alpha$ $=5 \%(0.05)$

- Rejection criteria

$\mathrm{H} 0$ is rejected if the $p$-value $<\alpha(0.05)$ or $\mathrm{F}$ hit> F table

- Decision
Based on the above output is known that $p$-value $(0.000)<\alpha(0.05)$ then $\mathrm{H}_{0}$ is rejected. So There is the influence of pretest and post-test in test Carthweel.

- Conclusion

It can be concluded no effect (improving student learning outcomes after given treatments using direct learning model) on the pre-test and post-test on the test Carthweel in SMA Negeri 1 Haurgeulis.

\section{Inquiry Learning Model}

ANOVA

Test Scores Tiger Sprong

\begin{tabular}{lrrrrr}
\hline & Sum of Squares & df & mean Square & F & Sig. \\
\hline Between Groups & 302500 & 1 & 302500 & 244574 & .000 \\
Within Groups & 47,000 & 38 & 1,237 & & \\
\hline Total & 349500 & 39 & & & \\
\hline
\end{tabular}

- hypothesis statistical

$\mathrm{H}$ 0: No effect of pre-test and post test in tiger jump.

$\mathrm{H}_{1}$ : There is the influence of pre-test and post test in tiger jump.

- Signification standart

In this case used a significance level of $\alpha=$ $5 \%(0.05)$
- Rejection criteria

$\mathrm{H} 0$ is rejected if the $p$-value $<\alpha(0.05)$ or $\mathrm{F}$ hit> F table

- Decision

Based on the above output is known that $p$ value $(0.000)<\alpha(0.05)$ then $\mathrm{H}_{0}$ is rejected. So There is the influence of pre-test and post test in tiger jump. 
- Conclusion

It can be concluded no effect (improving student learning outcomes after given treatments using inquiry learning model) pre-test and post-test on a test jump tiger in SMA Negeri 1 Haurgeulis.

ANOVA

Test Scores Carthweel

\begin{tabular}{cccccc}
\hline & Sum of Squares & Df & mean Square & F & Sig. \\
\hline Between Groups & 372100 & 1 & 372100 & 222674 & .000 \\
Within Groups & 63,500 & 38 & 1,671 & & \\
\hline Total & 435600 & 39 & & & \\
\hline
\end{tabular}

- hypothesis statistical

$\mathrm{H}$ 0: No effect of pre-test and post-test in test meroda.

$\mathrm{H}_{1}$ : There is the influence of pre-test and post-test in test carthweel.

- Signification standart

In this case used a significance level of $\alpha$ $=5 \%(0.05)$

- Rejection criteria

$\mathrm{H} 0$ is rejected if the $p$-value $<\alpha(0.05)$ or $\mathrm{F}$ hit> F table

- Decision

Based on the above output is known that $p$ value $(0.000)<\alpha(0.05)$ then $\mathrm{H}_{0}$ is rejected.

So There is the influence of pre-test and post-test in test carthweel.

- Conclusion

It can be concluded no effect (improving student learning outcomes after given treatments using inquiry learning model) at $\mathrm{p}$ re-test and post test on the test carthweel in SMAN 1 Haurgeulis.

\section{CONCLUSION \& SUGGESTION}

\section{Conclusion:}

1. There are some impacts of the direct instruction against the results of the gymnastics floor in SMA N 1 Haurgeulis.

2. There are some impacts of the indirect instruction against the result of the gymnastics floor in SMA N 1 Haurgeulis.

\section{Suggestion:}

1. For all the teachers of psychical education I wish that they are more consider the method of direct and indirect lessons models to be applied in the process of learning so the students can make a progress of the subject. Because in this model the students were given an example and the freedom to do the moves of the gymnastics floor.

2. For students, in this lessons can apply the the models of direct and indirect instruction to follow the the process of the lessons to become active, with more passion, enthusiastic, and more funny. Because the active students in the process of the lessons will capable to do the moves of the gymnastics floor.

3. For next researchers are expected to do a research on the effect of direct learning model (indirect instruction) and inquiry learning model (indirect instruction) in junior high or elementary school.

\section{REFERENCES}

Bauman, James. (2012). The Effectiveness of a Direct Intruction Paradigm for Teaching Main Idea Comprehension.Journal of International Reading Association.

Christofori, Pamela. (2005). The Effect of Direct Intruction Math Curriculum on Higher-Order Problem Solving.Journal of University of South Florida.

Ewing, Bronwyn (2011). Direct Intruction In Mathematics : Issues For School With High Indigenous Enrolments : A Liretature Review. Journal of Teacher Education. 36 (5), 65-92.

Fallah, Elhamdkk. (2015). The Effect of Eight Weks of Gymnastic Exercise on Develovement of Gross Motor Skills of Five to Six Years Old Girls. Journal Of Natural and Social Sciences.

Gagnon dan Maccini. (2011). An International Multidisciplinary Journal Ethiopia. Journal Physical Education 
Gurvitchdan Metzler. (2013).Aligning Learning Activities with Instructional Models.Journal of Phisical Education \& Dance.

Nasution.(2004). Metode Research.Bandung : PT. Jemar.

Juliantine, T. Subroto, T. \& Yudiana, Y. (2013). Model-Model Pembelajaran pendidikan jasmani. Bandung : FPOK UPI.

Setiawan W. dkk. (2010).Penerapan Model PengajaranLangsung (Direct Intruction) untukmeningkatkanpemahaanabelajarsis wadalampembelajaranrekayasaperangk atlunak (RPL).JurnalPendidikanTeknologiInfor masidanKomunikasi. 1-10

Sugiyono.(2012). Metode Penelitian Pendidikan. Bandung: Alfabeta.

Susilana, Rudi. (2006). Kurikulum Dan Pembelajaran. Bandung: Fip Upi

Yoga, EkaSepardita, dkk. (2014).Implementasi Kooperatif Untuk Meningkatkan Aktivitas dan Hasil Belajar Berguling Senam Lantai. Jurnal Pendidikan Jasmani dan Rekreasi. 